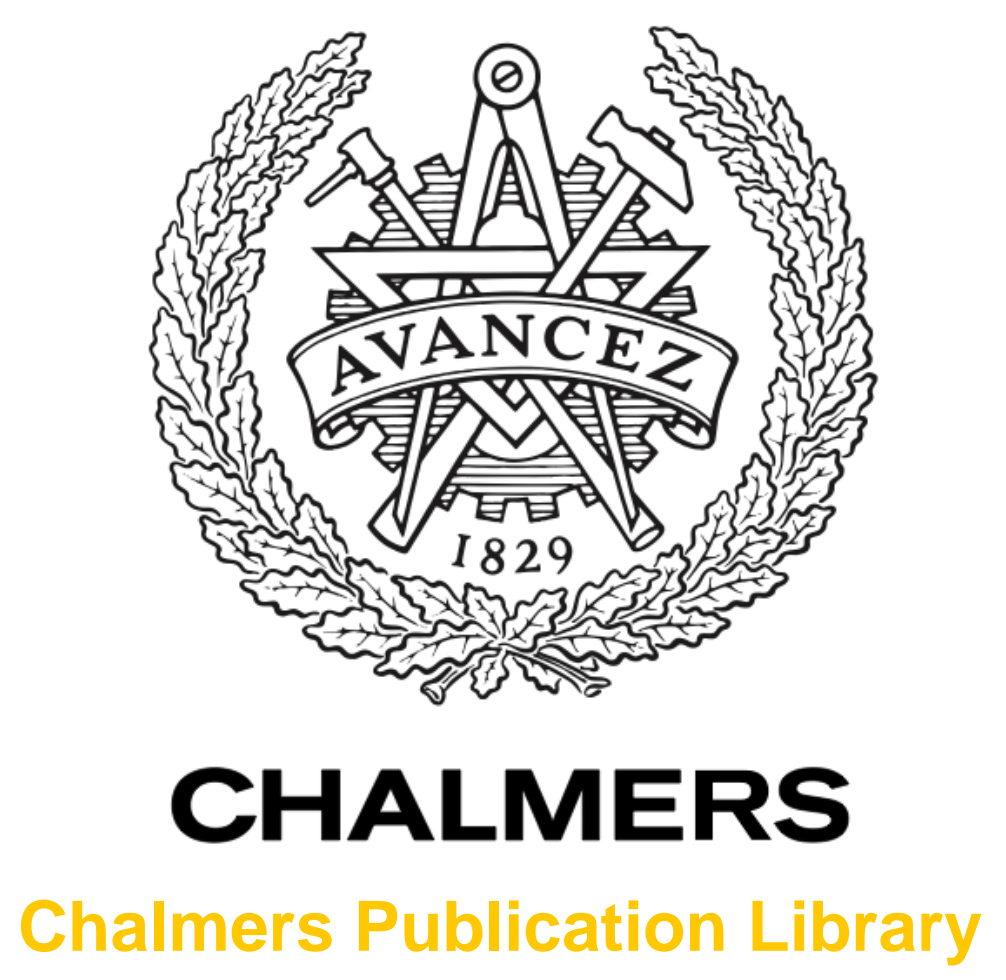

\title{
Reversed air staging - a method for reduction of N2O emissions from fluidized bed combustion of coal
}

This document has been downloaded from Chalmers Publication Library (CPL). It is the author's version of a work that was accepted for publication in:

Fuel

Citation for the published paper:

Lyngfelt, A. ; Åmand, L. ; Leckner, B. (1998) "Reversed air staging - a method for reduction of N2O emissions from fluidized bed combustion of coal". Fuel, vol. 77(9-10), pp. 953-959.

Downloaded from: http://publications.lib.chalmers.se/publication/5023

Notice: Changes introduced as a result of publishing processes such as copy-editing and formatting may not be reflected in this document. For a definitive version of this work, please refer to the published source. Please note that access to the published version might require a subscription. 


\title{
Reversed air staging - a method for reduction of $\mathrm{N}_{2} \mathrm{O}$ emissions from fluidized bed combustion of coal
}

\author{
Anders Lyngfelt*, Lars-Erik Åmand and Bo Leckner \\ Department of Energy Conversion, Chalmers University of Technology, 41296 Göteborg, Sweden \\ (Received 22 September 1997; revised 22 December 1997)
}

\begin{abstract}
Reversed air staging, a method for reduction of $\mathrm{N}_{2} \mathrm{O}$ emissions, was studied in a $12 \mathrm{MW}$ circulating fluidized bed boiler. The effect of combustor air-ratio, bed temperature, load and limestone addition ratio was investigated. The results indicate that if only the air distribution is changed, the emission of $\mathrm{N}_{2} \mathrm{O}$ can be decreased to one fourth compared to normal air staging at a temperature of $850^{\circ} \mathrm{C}$, with maintained low emissions of $\mathrm{NO}, \mathrm{SO}_{2}$ and CO. With increased bed temperature, $870^{\circ} \mathrm{C}$, in combination with increased limestone addition, from $\mathrm{Ca} / \mathrm{S}$ molar ratio $=3$ to 4 , it was possible to reduce $\mathrm{N}_{2} \mathrm{O}$ by $90 \mathrm{vol} \%$ with low emissions of $\mathrm{NO}, \mathrm{SO}_{2}$ and $\mathrm{CO}$. The method was less efficient at low load, because of the lower cyclone temperature. Also the effect of redistribution of some of the air added in the cyclone outlet to the cyclone inlet was studied. This did not, however, give any improvement in the boiler used compared to adding all of the air in the cyclone outlet. There was no significant difference in combustion efficiency between reversed air staging and normal air staging. (C) 1998 Elsevier Science Ltd. All rights reserved
\end{abstract}

(Keywords: $\mathrm{N}_{2} \mathrm{O}$; fluidized-bed; combustion)

\section{INTRODUCTION}

$\mathrm{N}_{2} \mathrm{O}$ is involved in both the greenhouse effect and in the destruction of the Earth's protective stratospheric ozone gas layer. Flue gases from fluidized bed combustion (FBC) of coal have significantly higher concentrations of $\mathrm{N}_{2} \mathrm{O}$ than other combustion techniques and may, if not abated, constitute a problem if the use of $\mathrm{FBC}$ becomes widespread. The discovery of high $\mathrm{N}_{2} \mathrm{O}$-emissions from $\mathrm{FBC}$ has launched a considerable research effort and the knowledge in the area is accumulating rapidly. Important results are available in the literature $e^{1-17}$

Most of the work published is concerned with the understanding of formation/destruction mechanisms, although some work has been initiated on methods for $\mathrm{N}_{2} \mathrm{O}$ reduction ${ }^{6,18,19}$.

The two major parameters for controlling the environment in the combustion chamber of a fluidized bed boiler (FBB) are temperature and air supply. Air staging, i.e. primary air ratio, has only a small effect on $\mathrm{N}_{2} \mathrm{O}$ emissions ${ }^{16}$. However, it is well known that $\mathrm{N}_{2} \mathrm{O}$ emissions can be decreased by either increased temperature or by decreased air-ratio. The problem is that these two parameters also affect NO-emission, sulphur capture and combustion efficiency. The situation is summarized in Figure 1, which shows the effect of increased temperature and increased air-ratio (more oxidizing conditions) on the emissions of $\mathrm{NO}, \mathrm{N}_{2} \mathrm{O}, \mathrm{SO}_{2}$ and $\mathrm{CO}$. (The latter also represents the general effect on combustion efficiency.) Normally, the $\mathrm{N}_{2} \mathrm{O}$-emission cannot be significantly

* Author to whom correspondence should be addressed. Tel: +46-31-772 1427; Fax: +46-31-772 3592; e-mail: anly@entek.chalmers.se decreased by re-optimizing the operation of a boiler because of the adverse effects on $\mathrm{NO}, \mathrm{SO}_{2}$ and combustion efficiency. Thus, the problem is not really how to reduce $\mathrm{N}_{2} \mathrm{O}$, but how to reduce $\mathrm{N}_{2} \mathrm{O}$ without introducing adverse effects on other emissions and combustion efficiency. This means that a simple re-optimization of operation parameters, such as temperature and air-ratio, is not sufficient to solve the problem of $\mathrm{N}_{2} \mathrm{O}$ reduction in $\mathrm{FBC}$.

Two methods for $\mathrm{N}_{2} \mathrm{O}$ reduction, afterburning and reversed air staging, have been studied in a $12 \mathrm{MW}$

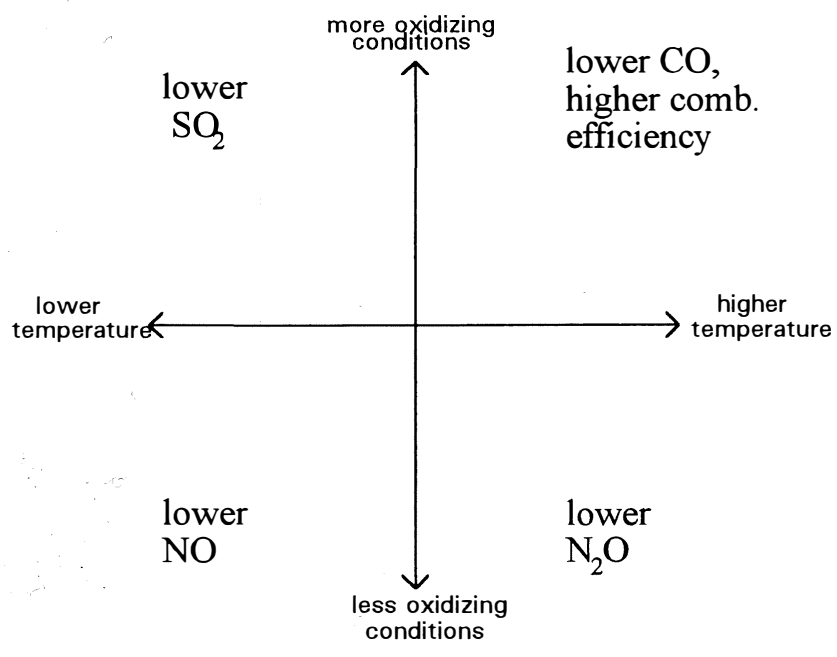

Figure 1 The optimization problem of fluidized bed combustion. The effect of changing temperature and air-ratio (oxidizing/ reducing conditions) on various emissions and combustion efficiency is indicated 


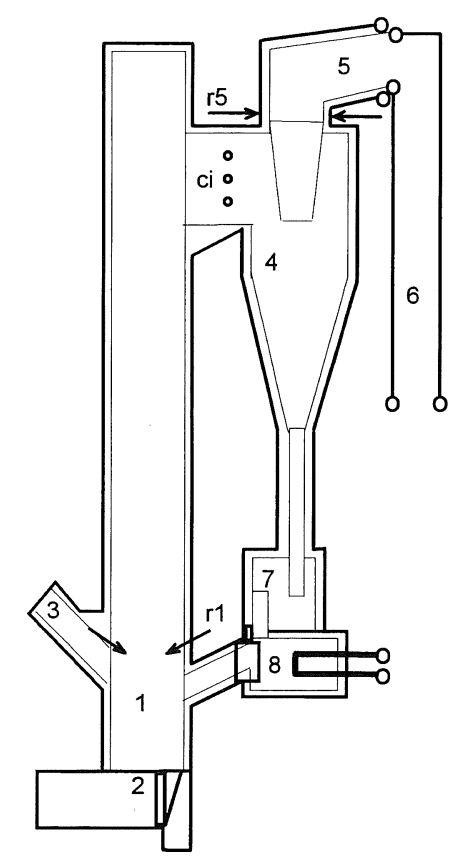

Figure 2 The Chalmers 12 MW boiler. (1) combustion chamber; (2) air plenum and start-up combustion chamber; (3) fuel feed chute; (4) cyclone; (5) exit duct; (6) convection cooling section; (7) particle seal; (8) particle cooler; $\rightarrow,{ }^{\circ}$, secondary air nozzle inlets: $\mathrm{r} 1$ at $2.2 \mathrm{~m}, \mathrm{r} 5$ in cyclone outlet, ci in cyclone inlet

Table 1 Fuel and sorbent data

\begin{tabular}{|c|c|}
\hline Fuel & Bituminous coal \\
\hline Size & $<16 \mathrm{~mm}(50 \%>5 \mathrm{~mm})$ \\
\hline Moisture wt $\%$ & $14.4 \pm 0.5$ \\
\hline Ash wt\% & $7.3 \pm 0.3$ \\
\hline Volatiles, wt $\%$ daf & 36 \\
\hline Carbon, wt $\%$ daf & $84.0 \pm 0.5$ \\
\hline Hydrogen, wt $\%$ daf & $5.82 \pm 0.06$ \\
\hline Nitrogen, wt $\%$ daf & $1.74 \pm 0.02$ \\
\hline Oxygen, wt $\%$ daf & $\approx 7$ (calculated $)$ \\
\hline Sulphur, wt $\%$ daf & $1.58 \pm 0.03$ \\
\hline Sorbent & Ignaberga limestone \\
\hline Size & $0.2-2 \mathrm{~mm}$ \\
\hline $\mathrm{CaCO}_{3} \mathrm{wt} \%$ & 90 \\
\hline
\end{tabular}

circulating fluidized bed boiler ${ }^{17,19,20}$. With reversed air staging, the air-ratio in the bottom part is raised and the air-ratio in the upper part of the combustion chamber is lowered, as compared to normal air staging. More oxidizing conditions in the bottom part are beneficial for sulphur capture and do not affect the $\mathrm{N}_{2} \mathrm{O}$ emission, while the lower air ratio in the upper part and the cyclone results in a significant lowering of the $\mathrm{N}_{2} \mathrm{O}$ emission. It has recently been demonstrated ${ }^{21}$, by oxygen probe measurements inside the combustion chamber, that the conditions in the riser are reversed compared to normal air staging. The present study is an extension of previous work on reversed air staging, which indicated that the effect of increased temperature and decreased load needs to be studied further ${ }^{20}$. In addition, the role of the conditions in the cyclone relative to the conditions in the riser was not clear. This aspect is also included in the present study with two test series showing the effect of redistributing some of the air added in the cyclone outlet to the cyclone inlet.

\section{EXPERIMENTAL}

The $12 \mathrm{MW}$ circulating FBB used for the experiments has the features of a commercial boiler, but was built for the purpose of research. The boiler is equipped for various types of measurements and has facilities that make it possible to vary parameters independently and in a wider range than in a commercial boiler. The boiler can also be operated under extreme conditions inappropriate to commercial boilers.

The boiler is shown in Figure 2. The height of the combustion chamber is $13.5 \mathrm{~m}$ and the square cross-section is about $2.5 \mathrm{~m}^{2}$. Fuel is fed to the bottom zone of the combustion chamber through a fuel chute (3). Primary air is introduced through nozzles in the bottom plate (2) and secondary air can be injected through several nozzle registers located horizontally on both sides of the combustion chamber. In the case of reversed air staging, air is introduced through the bottom plate (2) and in the cyclone outlet (5) to allow as long a gas residence time as possible before final air for completion of combustion is added. In this boiler there is a hot combustion space (5) before the gases are cooled in the convection path (6). In two of the test series some air was also introduced in the cyclone inlet (ci). Entrained bed material is captured in the hot, refractorylined cyclone (4) and returned to the combustion chamber through the return leg and particle seal (7). Figure 2 does not show the flue-gas recycling system, which supplies flue gas to the combustion chamber for fine tuning of the temperature in the boiler. Large, intentional changes in temperature can be made using the external, adjustable particle cooler (8).

Daily calibrated on-line gas analysers were used for continuous monitoring of $\mathrm{O}_{2}, \mathrm{CO}, \mathrm{SO}_{2}, \mathrm{NO}, \mathrm{N}_{2} \mathrm{O}$ and total hydrocarbons. Except for one oxygen analyser which was sampling in the convection pass, all the analysers were supplied with cooled and dried gas sampled in the gas duct downstream of the baghouse filter. The emissions of $\mathrm{SO}_{2}$, $\mathrm{NO}, \mathrm{N}_{2} \mathrm{O}$ and $\mathrm{CO}$ have been normalised to a flue gas with an oxygen concentration of $6 \mathrm{vol} \%$. Before the gas was introduced to the $\mathrm{N}_{2} \mathrm{O}$ analyser, the $\mathrm{SO}_{2}$ in the flue gas was captured in a solution of carbonate, since the $\mathrm{N}_{2} \mathrm{O}$ analyser is affected by high $\mathrm{SO}_{2}$ concentrations (above 500 ppmv). The mass fraction of combustibles in the ash samples was determined from mass loss during combustion at $815^{\circ} \mathrm{C}$.

The total air-ratio of the boiler, $\lambda_{\text {tot }}$, defined as the airratio after addition of final air in the cyclone exit, was kept constant at 1.2 during all tests. By combustor air-ratio is meant the air-ratio corresponding to the conditions in the riser, i.e. before addition of air in the cyclone exit or inlet. The combustor air ratio, $\lambda_{c}$, is

$$
\lambda_{\mathrm{c}}=1+K_{\mathrm{c}}\left(\mathrm{O}_{2}-\frac{21 x}{1+y+\left(K_{\mathrm{c}}-1\right) / \lambda_{\text {tot }}}\right) /\left(21-\mathrm{O}_{2}\right)
$$

where $\mathrm{O}_{2}$ is percentage of oxygen in the flue gas (including moisture) as measured in the convection pass, $K_{\mathrm{c}} \approx 1.07$ is the ratio of theoretical flue gas (including moisture) to theoretical air, $y$ is the ratio of flue gas recirculation to total air flow, and $x$ is the fraction of total air which is introduced in the cyclone outlet. If $K_{\mathrm{c}}$ is approximated by unity, the combustor air-ratio is given by the simpler relation

$$
\lambda_{\mathrm{c}} \approx \lambda_{\text {tot }}[1-x /(1+y)] \text {. }
$$

The air-ratio in the cyclone is equal to the combustor 
Table 2 The reversed air staging series studied

\begin{tabular}{lllllll}
\hline Series & Symbol & Temperature & Limestone & Load & Air cycl entr & Ca/S (molar ratio) Fig. \\
\hline Ref. & O & 850 & normal & full & - & 3.1 \\
High temp & T & 870 & normal & full & - & 3.0 \\
Extra lime & E & 870 & high & full & - & $3.4 / 3.8$ \\
Low load & L & 850 & normal & $70 \%$ & - & 3.6 \\
Both T and L & B & 870 & normal & $70 \%$ & - & 3.6 \\
T, L and E & Z & 870 & high & $70 \%$ & - & 4.8 \\
& 8 & 850 & normal & full & 8 vol\% & 3.2 \\
& 3 & 850 & normal & full & 3 vol\% & 3.1 \\
\hline
\end{tabular}
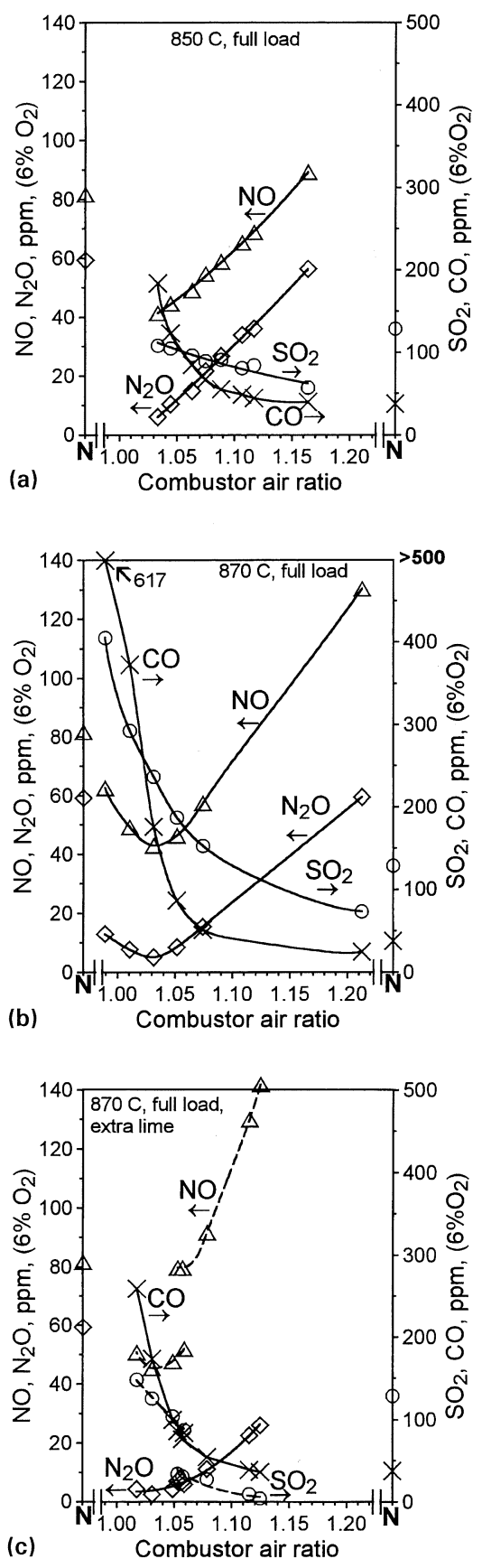

Figure 3 Full load: (a) reference series, i.e. $850^{\circ} \mathrm{C}$ and normal limestone addition (Emissions for normal air staging are shown on the vertical axes); (b) high temperature (Emissions for normal air staging are shown on the vertical axes); (c) high temperature and higher limestone addition. (Emissions for normal air staging are shown on the vertical axes) air-ratio, except for the two cases where air is added both in the cyclone inlet and in the cyclone outlet. In these two cases a cyclone air-ratio is also needed, see below.

All test cases were run at constant load, i.e. the combustion air added was kept constant at $3.5 \mathrm{~kg} / \mathrm{s}$ (full load), and the total air-ratio at $1.2\left(3.5 \mathrm{vol} \% \mathrm{O}_{2 \text {,wet }}\right)$. The total pressure drop over the height of the riser was $6 \mathrm{kPa}$. The sorbent was Ignaberga limestone and the coal was a British bituminous coal with a medium sulphur content. Limestone and fuel data are shown in Table 1.

\section{PROCEDURE}

The reference test series was full load, a bed temperature of $850^{\circ} \mathrm{C}$ and a limestone addition rate of $200 \mathrm{~kg} / \mathrm{s}$ corresponding to a $\mathrm{Ca} / \mathrm{S}$ molar ratio of about 3 . Eight test series were made, see Table 2. The first three series include (i) the reference series, (ii) increased temperature, and (iii) increased temperature combined with extra limestone addition. The next three test series are similar to the first three except that the load was reduced to $70 \%$ of full load. The two last series are based on the reference series, but with some air added in the cyclone entrance. The purpose of the latter two is to investigate how a rise in air-ratio from the riser to the cyclone affects the emissions under reversed air staging.

The procedure used in all the test series was to vary $x$, the fraction of the total air added in the cyclone exit, while keeping the total air-ratio, as well as other parameters of operation, constant. Thus, the total air flow to the boiler was constant, and an increase in the flow of air added to the cyclone exit (r5, Figure 2) resulted in an equal decrease in the air flow through the bottom plate (2, Figure 2). After each change of the air flow added to the cyclone exit the conditions were allowed to stabilize. The period between each change was typically one hour. The variation of the air flow added to the cyclone exit changes the combustor air-ratio, eqn (2), and the emissions are expressed as a function of the combustor air-ratio.

\section{RESULTS}

The emission data for the eight test series are shown versus combustor air-ratio in Figures 3-5. The results of reversed air staging should be compared to those of normal air staging at $850^{\circ} \mathrm{C}$, shown on the two vertical axes in each diagram and denoted by $\mathbf{N}$ on the horizontal scale but, of course, not related to the horizontal scale. With normal air staging is meant that about $60 \mathrm{vol} \%$ of total air is added through the bottom plate (2, Figure 2$)$, while $40 \%$ is added as secondary air at a height of $2.2 \mathrm{~m}$ (r1). The emissions under normal air staging were: $120-140 \mathrm{ppmv} \mathrm{SO}_{2}$, 80 ppmv NO, 40 ppmv $\mathrm{CO}$ and 60 ppmv $\mathrm{N}_{2} \mathrm{O}$.

A comparison between the results of Figures 3-5 may be 

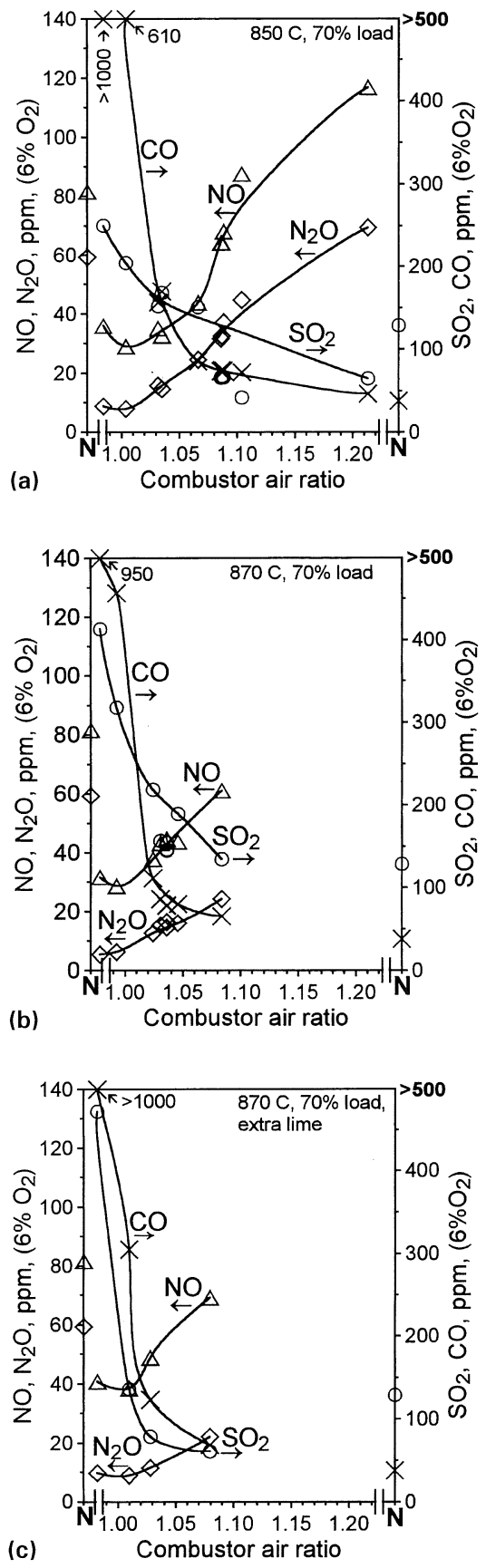

Figure 4 Low load: (a) $850^{\circ} \mathrm{C}$; (Emissions for normal air staging are shown on the vertical axes); (b) high temperature (Emissions for normal air staging are shown on the vertical axes); (c) high temperature and higher limestone addition. (Emissions for normal air staging are shown on the vertical axes)

difficult in some cases. Therefore, a more detailed analysis was made, where emission data for the various series were compared in the same diagram. Here, only an example is shown as in Figure 6, where $\mathrm{CO}$ is shown versus $\mathrm{N}_{2} \mathrm{O}$. Below the individual series are commented.

The reference test series shown in Figure 3(a) qualitatively resembles previous results. As the combustor air-ratio is lowered, the emissions of $\mathrm{NO}$ and $\mathrm{N}_{2} \mathrm{O}$ decrease, while $\mathrm{SO}_{2}$ and $\mathrm{CO}$ increase. At low combustor air-ratios $\mathrm{CO}$ increases dramatically. The figure indicates that $\mathrm{N}_{2} \mathrm{O}$ can be reduced to one fourth with $\mathrm{CO}$ below $100 \mathrm{ppmv}$.

The high emissions of $\mathrm{CO}$ at low air-ratios can be suppressed by increasing the temperature as shown by the
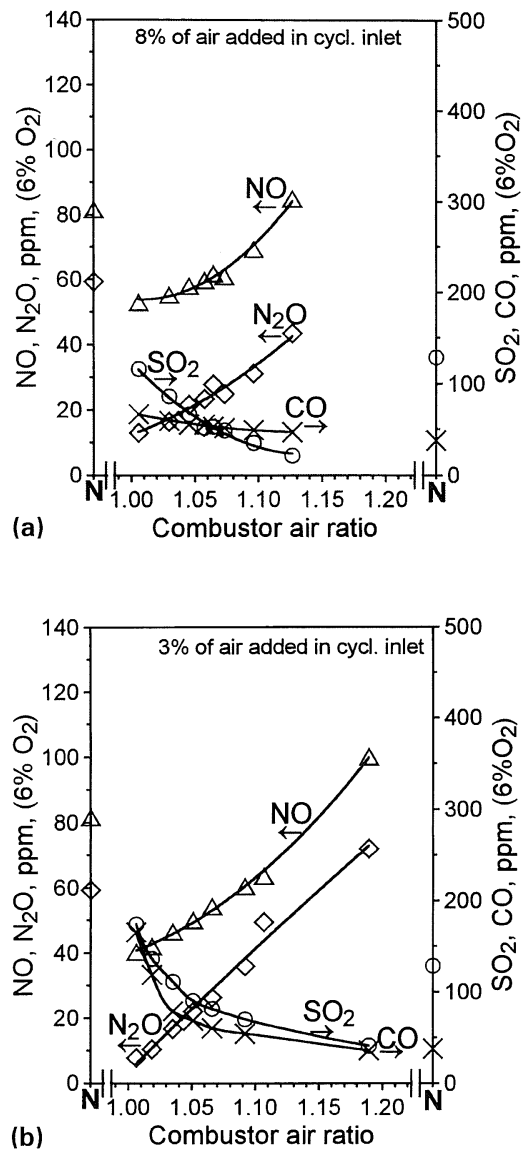

Figure 5 Part of the air is added in the cyclone entrance: (a) $8 \mathrm{vol} \%$ of total air in cyclone entrance (Emissions for normal air staging are shown on the vertical axes); (b) $3 \mathrm{vol} \%$ of total air in cyclone entrance. (Emissions for normal air staging are shown on the vertical axes)

high temperature series in Figure 3(b). The price paid for this decrease in $\mathrm{CO}$ emissions is higher $\mathrm{SO}_{2}$ emissions. In addition, the $\mathrm{N}_{2} \mathrm{O}$ emissions are further lowered while the emission of $\mathrm{NO}$ rises.

The higher $\mathrm{SO}_{2}$ emissions at the higher temperature can be reduced by a higher limestone addition rate as shown in Figure 3(c). The higher limestone addition also results in even lower $\mathrm{N}_{2} \mathrm{O}$ emissions, below 5 ppmv. Thus, a

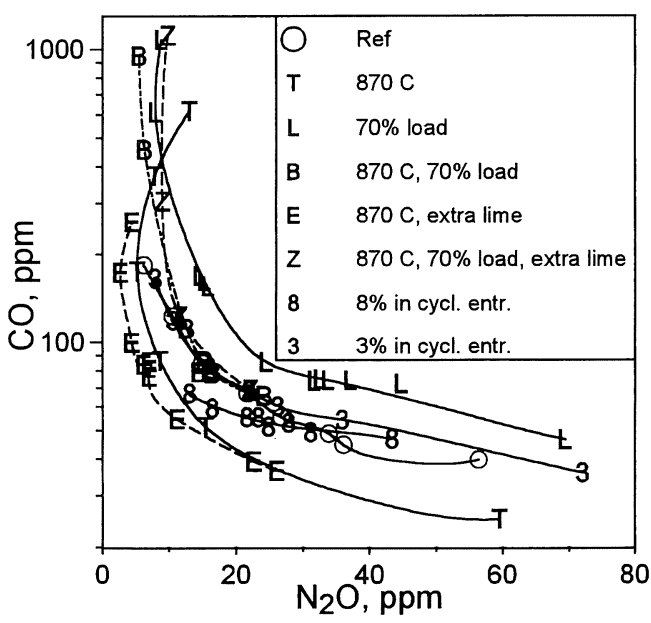

Figure $6 \mathrm{CO}$ versus $\mathrm{N}_{2} \mathrm{O}$ 


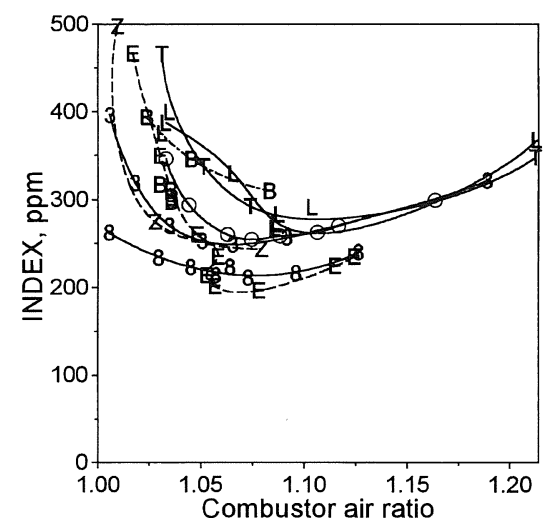

Figure 7 Emission index versus combustor air ratio. (Symbols, see Figure 6.)

reduction of $\mathrm{N}_{2} \mathrm{O}$ with 90 vol\% compared to the normal air staging case is realized in combination with low emissions of $\mathrm{NO}, \mathrm{SO}_{2}$ and $\mathrm{CO}$.

In Figure 3(c) there is a discontinuity in the graphs for $\mathrm{NO}$ and $\mathrm{SO}_{2}$. This is caused by different $\mathrm{Ca} / \mathrm{S}$ molar ratios. (In contrast to all other series, the series shown in Figure 3(c) includes data from two occasions with somewhat different limestone flows, cf. Table 2.) The highest $\mathrm{Ca} / \mathrm{S}$ ratio gives lower $\mathrm{SO}_{2}$ and higher NO.

In Figure 4 the three series above are repeated at reduced load. The obvious effect of reduced load is higher $\mathrm{N}_{2} \mathrm{O}$ emissions, while the effect on the other emissions is moderate. The increase in the $\mathrm{N}_{2} \mathrm{O}$ emissions is a temperature effect. Although the bottom bed temperature is the same as in the normal load cases, there is a fall in temperature of about $15-20^{\circ} \mathrm{C}$ from the bottom bed to the riser top at reduced load, as opposed to normal load where there is instead a small temperature increase of $0-5^{\circ} \mathrm{C}$.

In Figure 5 the effect of adding some air to the cyclone entrance is shown. For the case with 8 vol\% of the total air flow added to the cyclone inlet, the cyclone air-ratio is obtained by adding 0.09 ( $\approx$ fraction of air $\times$ total air-ratio) to the combustor air-ratio. This means that the conditions are similar to those of the reference series, Figure 3(a), except that the air-ratio is higher in the cyclone. The increased air-ratio in the cyclone has a distinct effect on $\mathrm{N}_{2} \mathrm{O}$ and $\mathrm{NO}$, which increase, and on $\mathrm{CO}$ and $\mathrm{SO}_{2}$, which both decrease. The similar effect, but less strong, is seen in Figure 5(b) where the air in the cyclone entrance is kept constant at 3 vol\% of the total air flow, giving a cyclone airratio which is 0.03 greater than the combustor air-ratio. A difference between the two series with air addition in the cyclone entrance compared to the other series is that the $\mathrm{SO}_{2}$ emission increases relative to the $\mathrm{CO}$ emission. Although the addition of air in the cyclone entrance possibly gives some improvement when looking at $\mathrm{N}_{2} \mathrm{O}$ and $\mathrm{CO}$, Figure 6, it does, on the other hand, give a change for the worse when considering $\mathrm{N}_{2} \mathrm{O}$ and $\mathrm{SO}_{2}$. It can be concluded that, with the present boiler and the operating conditions used, addition of air in the cyclone entrance does not improve the results of reversed air staging. It can not be excluded, however, that the result would have been different in a larger boiler with a longer residence time available before the cyclone inlet.

To see how the lowest emissions can be obtained, an emission index is defined to express the total emission, but with a weight of two chosen for $\mathrm{N}_{2} \mathrm{O}$, to account for the two nitrogen atoms and also to emphasize the significance of

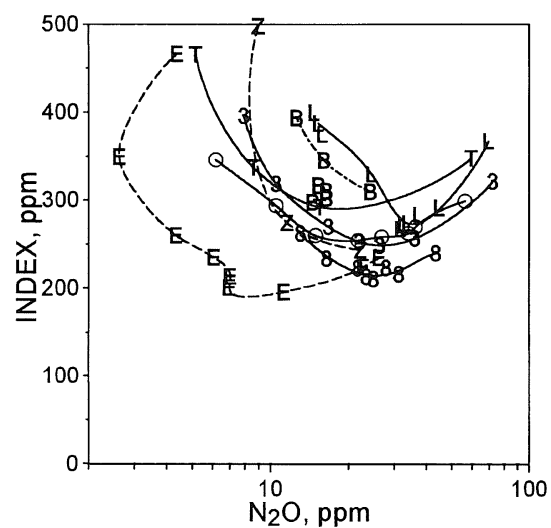

Figure 8 Emission index versus $\mathrm{N}_{2} \mathrm{O}$. (Symbols, see Figure 6.)

$\mathrm{N}_{2} \mathrm{O}$ :

$$
\text { Emission index }=2 \mathrm{p}_{\mathrm{N}_{2} \mathrm{O}}+\mathrm{p}_{\mathrm{NO}}+\mathrm{p}_{\mathrm{SO}_{2}}+\mathrm{p}_{\mathrm{CO}}
$$

where $p_{\mathrm{N}_{2} \mathrm{O}}$ etc. are the emissions in ppm normalized to a flue gas with 6 vol\% oxygen. The value of the emission index for normal air-staging is about $370 \mathrm{ppmv}$. The emission index shown versus combustor air-ratio in Figure 7, indicates that the total emissions can be decreased compared to normal air staging in all the cases of reversed air staging studied. The two series giving lowest emissions are the series with 8 vol\% air in the cyclone inlet and the series with increased temperature and limestone addition. However, of the two series only the latter reaches very low emissions of $\mathrm{N}_{2} \mathrm{O}$ as seen in Figure 8, where the emission index is shown versus $\mathrm{N}_{2} \mathrm{O}$. The emission of $\mathrm{N}_{2} \mathrm{O}$ can be decreased below 10 ppmv at the same time as the emission index is kept low.

In addition to $\mathrm{CO}$ also total hydrocarbons were measured (as methane equivalents). In connection with low $\mathrm{CO}$ emissions the amount of hydrocarbons was too low to give any safe results as the measured data varied from -1 to 4 ppmv. No significant difference in hydrocarbon emission compared to normal air staging was seen, but there was a very distinct correlation between hydrocarbon and $\mathrm{CO}$ emissions. The slope of hydrocarbons versus $\mathrm{CO}$ was 0.01 , i.e. each increase in $\mathrm{CO}$ with 100 ppmv was accompanied by an increase in hydrocarbons of $1 \mathrm{ppmv}$.

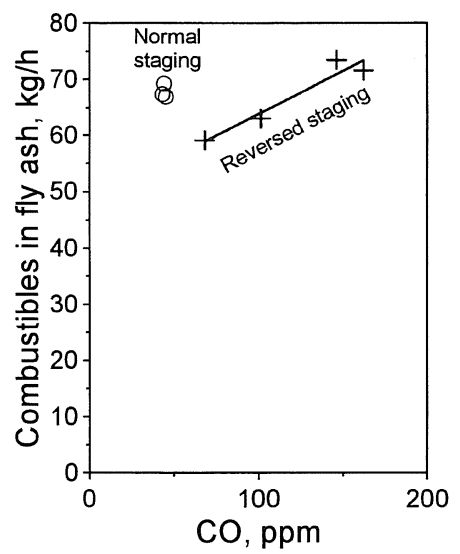

Figure 9 Loss of combustibles in fly-ash versus emission of $\mathrm{CO}$. Normal air staging $(O)$; reversed air staging $(+)$ 
Previous tests ${ }^{20}$ indicated that the combustion efficiency was not affected by reversed air staging except in connection with high CO-emissions, above 200300 ppmv. This is verified in Figure 9 which shows the loss of combustible matter versus the emission of $\mathrm{CO}$ in the two staging cases: clearly there is no significant difference in combustion efficiency between the two staging cases. The data in Figure 9 were obtained according to eqn (4)

$$
\dot{L}_{\mathrm{comb}}=\dot{m}_{\mathrm{c}} c_{\mathrm{c}}+\dot{m}_{\mathrm{f}} c_{\mathrm{f}}
$$

where $\dot{m}_{\mathrm{c}}$ and $\dot{m}_{\mathrm{f}}$ are the exiting mass flows of ash from the secondary cyclone and the textile filter, $c_{\mathrm{c}}$ and $c_{\mathrm{f}}$ are the mass fractions of combustible matter in these flows and $\dot{L}_{\text {comb }}$ is the loss of combustible matter from the system.

\section{DISCUSSION}

The $\mathrm{Ca} / \mathrm{S}$ ratios used, about 3.0, giving approximately $90 \mathrm{wt} \%$ sulphur retention in the normal air staging case, reflect the sulphur capture performance of the CFB boiler used. A comparison with two larger CFB boilers ${ }^{22}$, clearly indicates that the larger boilers have a more efficient sulphur capture. This is also the case for the combustion efficiency where the smaller Chalmers boiler has a considerably lower combustion efficiency with coal firing, about 94-95\%, compared to the two larger boilers.

A comparison of the emission results obtained for normal air staging from four different occasions gives an idea of the reproducibility of the results. Expressed in $1 \mathrm{~h}$ mean values these data typically show a small variation in $\mathrm{CO}$ and $\mathrm{N}_{2} \mathrm{O}$, \pm 2 ppmv, a somewhat larger variation in NO, \pm 5 ppmv, and the largest variation in $\mathrm{SO}_{2}, \pm 20 \mathrm{ppmv}$. NO was measured with two analysers in many of the tests, and the standard deviation was about 1 ppmv. The variation in $\mathrm{SO}_{2}$ when comparing the normal air staging runs is probably related to variations in $\mathrm{Ca} / \mathrm{S}$ molar ratio caused by variations in fuel sulphur content, since the variations in limestone flow were small. Thus, it can be concluded that there is a good reproducibility for $\mathrm{CO}, \mathrm{N}_{2} \mathrm{O}$ and $\mathrm{NO}$, while the reproducibility is lower for $\mathrm{SO}_{2}$. Therefore the comparison of the $\mathrm{SO}_{2}$ emission data of the various series should be made bearing in mind that the variation in $\mathrm{SO}_{2}$ is in the order of $\pm 20 \mathrm{ppmv}$.

The emission of $\mathrm{N}_{2} \mathrm{O}$ during normal air staging was considerably lower, about 60 ppmv, for the coal used in this study compared to coals of similar type previously used in the same boiler ${ }^{17,20}$. The reason for this is not clear, but is probably explained by a difference in the fuel properties.

\section{CONCLUSIONS}

In addition to reconfirming results previously obtained with reversed air staging, the following conclusions can be made from the study:

- A raised temperature suppresses the increase in $\mathrm{CO}$ observed during reversed air staging at lower air-ratios. However, the $\mathrm{SO}_{2}$ emissions increased.

- By the combination of higher temperature and higher limestone addition rate it was possible to reach very low emissions of $\mathrm{N}_{2} \mathrm{O}$, in combination with low $\mathrm{CO}$ and $\mathrm{SO}_{2}$ emissions. A reduction in $\mathrm{N}_{2} \mathrm{O}$ of 90 vol\% appears possible in combination with low emissions of $\mathrm{CO}, \mathrm{SO}_{2}$ and $\mathrm{NO}$.

- Previous preliminary results of a positive effect of reduced load were not confirmed. Except for the emission of $\mathrm{N}_{2} \mathrm{O}$, which increased owing to the lower cyclone temperature, the effect of load was small on the other emissions.

- Tests where air is entered in the cyclone inlet, at the same time as the air-flow to the cyclone exit is varied, clearly demonstrate the important role of the cyclone. In order to obtain very low emissions of $\mathrm{N}_{2} \mathrm{O}$ it was not sufficient to lower the air-ratio in the riser, but also the air-ratio in the cyclone had to be low.

- The combustion efficiency was not affected by reversed air staging.

\section{ACKNOWLEDGEMENTS}

This work has received financial support from the Swedish National Board for Industrial and Technical Development (NUTEK).

\section{REFERENCES}

1 Hayhurst, A. N. and Lawrence, A. D., Prog. Energy Combust. Sci., 1992, 18, 529-532.

2 Mann, M. D., Collings, M. E. and Botros, P. E., Prog. Energy Combust. Sci., 1992, 18, 447-461.

3 Wójtowicz, M. A., Pels, J. R. and Moulijn, J. A., Fuel Process. Technol., 1993, 34, 1553-1561.

4 Kramlich, J. C. and Linak, W. P., Prog. Energy Combust. Sci., 1994, 20, 149-202.

5 Johnsson, J.-E., Fuel, 1994, 73, 1398-1415.

6 Lyngfelt, A., Åmand, L.-E. and Leckner, B., Nitrous oxide from fluidized bed boilers. In Encyclopedia of Environmental Analysis and Remediation. Wiley, New York, in press.

7 Hulgaard, T., Nitrous oxide from combustion. Thesis, Department of Chemical Engineering, Technical University of Denmark, Lyngby, 1991.

8 Pelz, G., $\mathrm{N}_{2} \mathrm{O}$-Emissionen aus kohlegefeuerten Kraftwerksanlagen. Thesis, Paderborn University, Paderborn, Germany, 1993.

9 Miettinen, H., Formation and decomposition of nitrous oxide at fluidized bed conditions. Thesis, Department of Inorganic Chemistry, Chalmers University of Technology, Göteborg, 1995.

10 Tullin, C., Emissions of $\mathrm{N}_{2} \mathrm{O}$ and $\mathrm{NO}$ from single particles of coal under fluidising bed combustion conditions. Thesis, Department of Inorganic Chemistry, Chalmers University of Technology, Göteborg, 1995.

11 Pels, J. R., Nitrous oxide in coal combustion. Thesis, Dept. of Chemical Engineering, Delft University of Technology, Delft, The Netherlands, 1995.

12 Winter, F., Single fuel particle and $\mathrm{NOx} / \mathrm{N}_{2} \mathrm{O}-\mathrm{emission}$ characteristics under (circulating) fluidized bed combustor conditions. Thesis, Institute of Chemical Engineering, University of Technology, Vienna, 1995.

13 Hämäläinen, J., Effect of fuel composition on the conversion of fuel-N to nitrogen oxides in the combustion of small single particles. Thesis, Department of Chemistry, University of Jyväskylä, Jyväskylä, Finland, 1995.

14 Jensen, A., Nitrogen chemistry in fluidized bed combustion of coal. Thesis, Department of Chemical Engineering, Technical University of Denmark, Lyngby, 1996.

15 Kilpinen, P., Kinetic modeling of gas-phase nitrogen reaction in advanced combustion processes. Thesis, Åbo Akademi, Åbo, Finland, 1992.

16 Åmand, L. -E., Nitrous oxide emission from circulating fluidized bed combustion. Thesis, Department of Energy Conversion, Chalmers University of Technology, Göteborg, 1994. 
17 Gustavsson, L., Reduction of $\mathrm{N}_{2} \mathrm{O}$ emission from fluidized bed combustion by afterburning. Thesis, Department of Energy Conversion, Chalmers University of Technology, Göteborg, 1995.

18 Wójtowicz, M. A., Pels, J. R. and Moulijn, J. A., Fuel, 1994, 73, 1416-1422.

19 Lyngfelt, A., Åmand, L. -E., Gustavsson, L. and Leckner, B., Energy Convers. Mngmt, 1996, 37, 1297-1302.

20 Lyngfelt, A., Åmand, L. -E., Karlsson, M. and Leckner, B., Reduction of $\mathrm{N}_{2} \mathrm{O}$ emissions from fluidised bed combustion by reversed air staging. In 2nd International Conference on Combustion and Emissions Control, The Institute of Energy, London, 1995.

21 Lyngfelt, A., Åmand, L. -E., Müller, E. and Leckner, B., Reversed air staging-a method to reduce nitrous oxide emissions from circulating fluidized bed boilers. In 7th International Workshop on Nitrous Oxide Emissions, Cologne, April 21-23, 1997.

22 Mattisson, T. and Lyngfelt, A., Chem. Engng Sci., 1998, 53, $1165-1175$. 